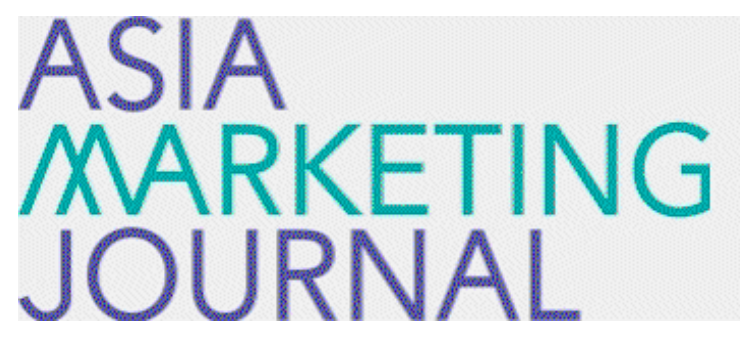

ASIA MARKETING JOURNAL

Volume 4 | Issue 3

Article 4

$9-1-2002$

\title{
롯데리아의 성공 사례
}

\section{Young Seok Son}

Jae II Kim

Follow this and additional works at: https://amj.kma.re.kr/journal

Part of the Marketing Commons

\section{Recommended Citation}

Son, Young Seok and Kim, Jae II (2002) "롣데리 아의 성 공 사례," Asia Marketing Journal: Vol. 4 : Iss. 3 , Article 4.

Available at: https://doi.org/10.53728/2765-6500.1091

This Article is brought to you for free and open access by Asia Marketing Journal. It has been accepted for inclusion in Asia Marketing Journal by an authorized editor of Asia Marketing Journal. 


\title{
롯데리아의 성공 사례 \\ :시장 선발기업 우위의 확보와 유지*
}

\section{The Case of Lotteria \\ : Building and Sustaining Entrenchment of Pioneering Advantage}

\author{
손영석(한림대 광고홍보학과 조교수) \\ ysgson@hallym.ac.kr \\ 김재일(서울대 경영학과 교수) \\ jaekimesnu.ac. kr
}

전세계적으로 햄버거를 중심으로 하는 패스트푸드산업에서 맥도날드가 모든 시장에서 1 위률 차지하고 있으나. 유독 한국의 롯데리아와 필리핀의 졸리비(Jolibee)에만 뒤져 각각 그 시장에서 2 위를 차지하고 있다. 본 연구에서는 이러한 롯데리아의 마케팅 역량을 형성하 는 요인을 분석한 결과, 각 시기별로 빠른 의사결정, 핵심상권 유통망 구축, 조직과 고객관 리, 경쟁사 대비 차별화, 고객만족등의 마케팅 노력이 핵심적인 역할을 했음을 알 수 있었 다.

또한 각 브랜드 성장단계별로 미국문화의 소개 브랜드로, 한국적이며 차별적인 메뉴와 맛, 그리고 가격으로 소비자들에서 성공적으로 포지셔넝한 졀과로 나타났다.

* 사례접수: 02,09 게재확정: 02,10 사례개발에 많은 도움을 주신 콧데리아 이철우사장넘이하 실 무진께 사의를 표합니다. 


\section{1. 서론}

2002년 현재 한국의 외식산업전체의 규모는 약 30 조원에 이르는 것으로 나타나고 있다. 외식산업에서 대표적인 업종인 패밀리레스토랑과 패스트푸드 시장도 매년 신장 속도가 뺄라 지면서 매출규모는 지난해 2조원에 이어 올해는 5 조원으로 추정되고 있다(www.fnnews.com). 그중에 패스트푸드시장의 시장규모는 약 1 조 2 천억원이며, 이 시장에서 지배적인 브랜드는 롯데리아로 시장전체에서 44 가라량의 점유율을 보이고 있고, 두 번째 브랜드로서는 맥도날드 가 차지하고 있다.

그러나 전세계적으로 햄버거를 중심으로 하는 패스트푸드산업에서 맥도날드가 모든 시장 에서 1 위를 차지하고 있으나, 유독 한국의 롯데리아와 필리핀의 졸리비(Jolibee)에만 뒤져 각각 그 시장에서 2 위를 차지하고 있다. 또한 롯데리아는 국내 패스트푸드 산업이 본격적으 로 도입된 이후 20 년이상 패스트푸드 시장을 지속적으로 1 위의 자리를 고수하는 경쟁력을 갖춘 기업이라는 점에서 마케팅적인 관점에서 주목할만하다.

롯데리아는 시장에서 지배적인 위치를 유지하기 위해서 2003년까지 매출 1조원 달성, 유 통점수 1천점 개설을 목표로 하고 있다. 이를 위해서 맥도날드이외의 다국적 브랜드들과 확 실하게 차별화되는 기업 이미지를 부각시키려고 한다.

그러면 과연 전국의 800 여개의 유통점에 매일 76 만명의 고객이 구매하며, 한달에 약 2 천2백 만명이 이용하는 이 거대한 패스트푸드 기업은 어떤 성공요인으로 지금껏 지위를 지켜왔는 지를 살펴보고, 이를 통해서 다른 기업에서도 전략적인 시사점을 얻는 것이 본 연구의 목표 이다.

\section{2. 우리나라의 외식 및 패스트푸드 산업 변천 과정}

\section{1 우리 나라 외식업소의 변천과정}

우리나라의 외식 풍속으로는 농번기에 일터에서 먹는 새참이나 화전놀이 때 부녀자들이 싸 가지고 가서 먹던 음식, 그리고 먼길을 떠날 때 일종의 비상 식량으로 가지고 다니던 음 식 등이 있다. 외식에 대한 최초의 기록은 고려 성종 2년(983년) 개성에 설치된 주막에서 비롯된다.

그 3년 뒤인 966년에는 처음으로 철전을 주조- 사용하였으므로 주막에서 음식값으로 철전 을 사용한것으로 추정된다. 고려 현종 원년(1010년)에는 절에서 술을 빚지. 못하게 함으로써 연등회나 팔관회 등에 사용하는 술을 자체적으로 조달하기 어렵게 되자 대신 목로를 설치해 일반인들이 이용할 수 있도록 하였다. 그 이듬해인 1011년에는 외국 사절이나 상인들을 대 상으로 하는 영빈관과 회선관이라는 객관을 설치하였다. 숙종 2년(1097년)에는 철전의 사용 과 유통을 장려하기 위해 개성에 좌우주점(左右酒店)을 개설하고, 차- 술- 음식 매매에는 반드시 철전을 쓰도록 했다. 그리고 고려 숙종 9년(1104년)에는 각 고을마다 주식점(酒食 (店)을 두어 여행자들에게 숙식을 제공토록 했다. 
조선시대에는 객주가 오늘날의 여인숙 겸 대중음식점 역할올 맡았다. 객주는 상품의 위탁 매매를 주업으로 하면서 숙박을 무료로 제공하는 물상객주와 식사와 잠자리를 주업으로 하 는 보상객주가 있었다. 이외에 지방 관리가 서울 올라올 때 숙박할 수 있는 경주인이 있었 다. 조선 시대의 음식 판매에 대해서는 $\mathbf{r}$ 동국세시기(東國歳時記)」에 시절(時節)음식으로 시 장에서 떡국을 팔았다는 기록이 전해진다. 그리고 고려 시대의 주막이나 주식점은 조선 시 대에도 이어졌으며, 얼마 전까지만 해도 시골 장터 같은 곳에 그 흔적이 남아 있었다.

주막이나 주점 중에서 조선조 후기에는 맛이 뛰어난 여러 업소가 나타났는데, 헌종 때에 는 무교동 탕반집이 매우 유명했다. 헌종조차도 사복으로 갈아입고 때때로 찾을 정도였다고 한다. 이 때문에 무교동 탕반집의 장국밥을 맛보기 위해 높은 벼슬아치들이 단골로 드나들 었다. 또한 경기도 광주 남한산성의 해장국은 재상집에서 배달올 시킬 정도로 유명했다. 밤 에 국항아리를 솜에 싸서 하인을 시켜 서울로 보내면 새벽종이 울릴 때쫌 도착했다고 해서 효종(曉鐘)국이라 했는데, 그때까지도 식지 않았다고 한다. 이러한 것올 보면 극히 제한적 이기는 했지만, 일부 업소에서는 영리를 추구하는 식당이 본격적으로 등장한 것은 구한말의 개화기 이후였다.

1883 년 말에는 양주가 처음으로 수입· 판매되었으며, 극히 제한적이기는 했지만, 숙박업 과 조리업이 발달하게 되었다. 1887년에는 서울에 일식 고급 요정인 정문루(井門樓)가 개점 한 뒤 1900 년에는 서울에만 12 개의 요리점이 사교중심지로 자리 잡았다. 1888년에는 한국 최초로 인천 서린동에 대불호텔이 문을 열고 인천항을 드나드는 선박을 상대로 식료품올 공 급하면서 음식점을 개설했다. 뒤이어 1900년에는 독일인에 의해 손탁호텔(Sontag llotel)이 서울 정동에서 문을 열어 국내 최초로 프랑스식 식당이 선보였다. 손탁호텔에서는 1882 년 궁중에 처음 들어와 고종황제가 즐겨 마시던 커피를 1902년부터 일반일들에게 판매하기도 했다. 1912년에는 조선 총독부 철도국에 의해 경의선의 종착점인 신의주와 경부선 종착점인 부산에 철도호텔이 각각 세워졌으며, 1914년에는 역시 조선 총독부 철도국에 의해 철도호텔 로 조선호텔이 등장하였다. 조선호텔의 등장은 서울지역에서의 다방과 식당이 본격적으로 발전하는 계기가 되었으며, 한일합방 이후 최초의 민간호텔로는 1936년에 반도호텔이 처음 세워지게 된다.

1945년 광복 당시 서울의 음식점 수는 불과 166개소에 불과했으며, 대표적인 음식점으로 는 이문 설렁탕(1901년), 용금옥(1930년), 곰보추어탕(1930년), 한일관(1934년), 청진옥 (1935년), 조선옥(1937년), 안동장(1940년), 고려당(1945년), 남포면옥(1948년), 하동관 (1948년) 등이었다. 그러나 이시기는 극도의 물자부족 시대로 음식은 전적으로 가정에서 해 결하던 때였다. 이후 1960년대에 들어서서 1963년 삼양라면이 최초로 시판되고, 1964년 비 어흘이 첫선올 보였다. 1966년에는 코카콜라가 국내에 상륙하고, 1967년 강남에 뉴욕제과가 문을 열었다. 1970년대에는 7월 7일 경부고속도로가 개통되면서 전국이 1일 생활권으로 좁 혀지고, 경제개발로 가계수입이 늘어나자 서서히 외식의 개념이 자리잡게 되었다.

이러한 사회적인 흐름에 따라 1979년 7월에 커피전문점인 난다랑이 지금의 대학로 샘터빌 딩에 점포을 열면서 프랜차이즈업체가 되었다. 그리고 1979년 10월 25일 롯데리아가 출범함 으로써 국내 외식업계 최초의 프랜차이즈 사업이 도입되었다.

\section{2 햄버거의 유래}

유럽인들은 중앙 아시아에서 극동에 이르는 초원 지대에 살던 민족을 타타르(Tartar)인 
이라고 불렀다. 타타르 인들은 오랜 시간 말을 타고 다니기 때문에 안장밑에 생고기를 깔고 다니기도 했다. 이러한 생고기 문화가 결국 헝가리등지에 전파되었고 또한 독일 상인들에 의해서 독일로 전파되었다. 독일 상인들은 한자 동맹이 결성된 후에 그 근원지인 합부로 그 를 중심으로 타타르 스테이크가 인기를 얻게 되었고 잘 다진 고기를 불에 굽는 요리법으로 발전하게 되었다. 이 때 음식 이름도 함부르크의 음식이라는 뜻으로 함부르크 스테이그 (Hamburg steak)로 바뀌었다. 이후 19세기가 끝날 무렵 타타르 스테이크는 함부르크에서 불 에 굽는 요리법으로 변화된 것에 연유해서 햄버거(Hamburg)라는 명칭을 얻게 되었다. 신대. 륙이 발견되고 난 이후에 속에 독일 이민자들을 통해서 함부르크 스테이크가 소개되었다.

최초로 상업화된 햄버거가 등장하게 된 것은 1904년 세인트루이스(Saint Louis) 세계 박 람회에서 시작되었다. 이 박람회장에서는 많은 사람들에게 빠른 시간 내 음식을 공급하기 위해서 둥근항에 번즈(burns)를 끼워서 먹는 기본적인 햄버거 형태롤 갖추었다. 이 박람희 에서는 아이스크림 콘과 아이스 티가 햄버거와 함께 유명해 진 제품으로 등장하였다.

\section{3. 패스트푸드 산업 발전 단계별로 구성한 롯데리아의 구축과 방어전략}

롯데리아는 한국의 패스트푸드업계에서의 최초 기업이므로 패스트푸드 산업의 발전단계와 성장궤적이 동일하므로 이를 통해서 각 시기별 전개된 전략과 결과를 살펴보도록 한다.

\section{1 제 1기 (패스트푸드 기업의 출현기 : -1980년 이전)}

1970년 말 당시 일본 패스트푸드 산업은 국민소득이 8500 달러로서 외식시장이 폭발적으로 신장하는 외식 혁명기에 해당되는 시기였다. 경쟁도 매우 치열하게 벌어져 일본 롯데리아를 비롯한 맥도날드, 모스버거, 일본 $\mathrm{KFC}$ 둥이 치열한 경쟁울 벌이고 있었으며, 막대한 자금력 을 앞세운 맥도날드가 급속도로 점포를 확대하는 상황에 놓여 있었다. 이러한 배경에는 일 본시장이 가지는 의미가 특별하기 때문이었다. 즉 일본에서의 성공은 다른 아시아시장의 교 두보 역할올 하므로 이 시장에서의 성공은 매우 중요한 의미가 담겨 있었기 때문이다.

한편 일본예서 다국적 패스트푸드 기업들이 격전을 치르면서 콧데리아는 1970년대 빠른 경제성장을 보인 한국시장올 예의주시한 결과, 한국에서도 외식에 대한 국민적인 욕구가 일 어나고 있음을 확인하고 한국시장을 선점하기로 결정하였다.

한국시장의 선점은 일본시장에서의 치열한 경쟁을 피하고 새로운 시장을 확보할 수 있다 는 전략적인 중요성이 있었다.

이에 따라서 1979년 5월 1일 콧데 제과 내의 롯데리아 사업부가 설치되었고, 1979년 10월 25 일 1호점인 소공동점 개점과 함께 신준호 그룹 운영 본부장이 대표 이사로 취임하면서 사 업이 시작되었다. 현재 기업명으로 사용하고 있는 롯데리아(Lotteria)는 롯데(Lotte)와 카 페테리아(Cafeteria)의 합성어이다. 원래 'Lotte'는 독일의 대문호 괴테가 지은 "젋은 베르 테르의 슬픔"에 등장하는 여주인공 '샤롯데'에서 유래된 것이며, 'Cafeteria' 와 합쳐젹 Lotteria' 라는 브랜드가 만들어졌다. 
한편 1978년경 화신 그룹에서는 미국 맥도날드와 제휴를 시도하였다. 그러나 맥도날드 본 부에서는 한국의 경제 규모나 국민 소득이 패스트푸드 사업을 전개하기에는 아직 이르다고 판단하여 국민 소득이 최소한 3,000 달러 $-5,000$ 달러 정도가 되어야 가능하다고 판단하였다.

왜나하면 1978년 당시의 한국의 국민 소득은 1,400달러이며, 가구당 외식비 역시 55,000 원 에도 미치지 못하여 맥도날드의 시장형성기준과는 많은 차이가 있었다.

롯데리아가 한국 시장에 진출하기 이전에 국내의 서구식 패스트푸드 시장에는 킹 햄버거 와 마그도날드라고 하는 업체가 있었다. 킹 햄버거는 용산 미군 기지 내의 PX업체이었으며, 마그도널드는 미국 맥도날드를 본떠서 만든 업체었다. 또한 명동 입구에 몌드리아라고 하 는 한단계 진전된 업체가 있었으나 경영 미숙으로 얼마 후 문을 닫았다.

한편 패스트푸드시장에서 본격적인 후발 브랜드들이 등장하기 시작한 것은 롯데리아의 매 출액이 급증하여 시장의 전망이 보이던 1980 년이었다. 1980 년 12 월 홍우건설이 순 매출액의 $1 \%$ 를 로열티로 지불하면서 미국의 빅보이와 제휴하여 아메리카나를 설립하였다. 아메리카나 는 자체 브랜드로서 50 평 정도의 매장을 서울의 주요 지역에 5 개의 매장을 개설하였으며, 전국적으로 약 100 여개의 매장을 개설할 예정이었다.

한편 협진양행도 1980 년 12 월 미국의 버거킹과 합작하여 버거킹 브랜드에 한국 시장에 진 출하였다. 이후 미국의 버거킹은 지속적으로 지분을 확대하였다.

\section{2 제2기 (패스트푸드 산업의 도입기 : 1981년-1984년 ; 핵심 상권 유통 망 구축 전략)}

\section{2 .1 시장상황}

1981년 아시안게임과 서울 올립픽게임의 유치에 성공하고, 1982년도에는 야간 통행 금지 가 해제되고, 프로 야구가 출범함에 따라서 여가 활동에 대한 새로운 계기가 마련되었다. 이결과 국내 외식 산업에도 큰 영향을 미치게 되었다. 즉 다국적 외식산업들이 한국 시장의 가능성올 확인하고 이 기간에 많은 진출이 있었다. 1981년에 미스터도너츠, 1982년에 윈첼도 너츠, 1983년에 던킨도너츠가 진출하였으며, 프라이드 치킨류로는 1983년 로열치킨, 1984년 켄터키 프라이드치킨등이 그리고 웬디스가 진출하였다.

따라서 1980 년을 기점으로 롯데리아는 이전의 군소업체와의 경쟁에서 이제는 미국의 3 대 패스트푸드 기업과의 경쟁이 벌어지게 되었다.

이들 기업과 경쟁하기 위해서는 유통망 확보를 최고의 전략적 과제로 선정하였다. 1981년 도에는 유톻망 확대를 위에서 기존의 점포 선정 기준을 수익성과 사업의 장래성을 기준으로 변경하였다. 또한 서울 시내의 핵심 상권의 전훌을 가속화하고 부도심권 점포 입지 본점에 나섰다. 이 시기 서울의 부도심권은 교통망의 급속한 발달로 상권 형성이 하루가 다르게 이 루어 지고 있었다. 이에 따라 청량리, 도곡동, 종로2가 고속 터미널둥에 점포를 개설하였다. 이 결과 1981년말에는 전체 12 개점이 개설되었다.

한편 패스트푸드산업의 후발 경쟁업체들도 기업 이미지 제고를 위해서 서울 명동과 종로 에 각각 대규모 매장을 개설하는 둥 치열한 경쟁에 돌입하였다. 롯데리아는 한 단계 더 나 아가 이들 경쟁업체들과 대웅하기 위해서는 서울뿐만 아니라 지방시장올 개척하는 것이 향 후 경쟁우위의 결정적인 관건이라고 판단하였다. 따라서 유통망 확장 전략으로서 지방의 인 구 20 만 이상의 도시에 대해서는 진출한다는 계획을 설립하고, 서울 수도권과 전철역세권, 
올림펵촌, 신규백화점에는 반드시 진출한다는 목표를 설정하였다.

이 결과 1982년에만 대구, 대전, 부산 그리고 광주에 각각 점포망올 확대하였으며, 울산 성남은 1984년에, 수원, 안양, 목포, 포항등 24개 도시는 1984년이 후에 진출하기로 결정하 였다. 그리고 기존의 소규모 매장을 확장하는 리뉴얼 공사를 하였다.

유통망 확대의 속도를 높이고 전직원의 참여를 유도하기 위해서 점포 개점 수상 제도를 도 입하였다. 이 제도는 전국 대도시를 중심으로 입지 여건이 좋은 점포를 소개하거나 또는 그 런 점포를 소유하거나 임대한 사람 가운데 롯데리아 점포 개설올 희맘하는 사람을 소개하는 직원에 대해서는 포상하는 것을 의미한다. 롯데리아는 이같이 사업 초기 연도에 4 년간 집중 적인 유통망 확보에 나섬으로써 그 결과 14 개 도시 직영점 12 개점, 가맹점 13 개점으로 모두 25개점으로 늘어났다.

\section{2 .2 확대된 유통망 관리를 위한 고객만족제도의 도입과 관리시스템 구축}

급속하게 늘어난 유통점을 관리하기 위해서 롯데리아는 고객 만족 제도를 적극적으로 추 진하였다. 1984년에는 고객 클레임 신고제를 도입하였다. 이 제도는 유통점내에 고객 불편 신고엽서와 패널 및 투입함을 비치하여 고객들이 느끼는 불편사항이나 개선점율 수럼하는 제도로 운영되는 것이었다. 이전까지는 본사에서 유통점에 대한 모니터제도를 시행하고 있 었는데, 고객 클레임제도가 도입됨에 따라서 고객들이 느끼는 불편을 직접적으로 파악할 수 있는 장점이 있었으며 불평불만 사항은 직접적으로 시정되었다.

또한 전 유통점에서 “메이트 두발기준 및 스마일 기준 액자” 를 비치하여, 근무자들이 항상 청결과 스마일 연습을 하여 고객올 응대할 수 있도록 하였다. 이것은 사실 개점초부터 정해진 관리방침이지만 더욱 강화하여 관리 프로그램으로 설정하였다.

한편 유통 확장에 따른 늘어난 점장들의 교육을 강화하여 점포 매니저 교욕프로그램을 집 중적으로 운영하여 1984년까지 135 명의 매니저가 고객들이 일관적인 서비스를 받을 수 있도 록 교육을 수료하였다. 교육기간은 기수별로 차이가 있으나 대략 2개월간의 이론과 실습교 육을 받도록 하였다. 이러한 매니저 교육 프로그램은 인력이 부족한 당시로서는 파격적인 교육기간으로서 유통관리에 심혈을 기울였던 노력의 일환이라고 할 수 있다.

\section{2 .3 다양한 마케팅 촉진활동}

한편 롯데리아는 유통망 확충과 더불어 이를 지원할 수 있는 촉진할동을 할발하게 전개하 였다. 광고는 크게 두가지 방향으로 전개되었다. 패스트푸드산업의 선두기업으로서 먼저 목 표 소비자들인 10 대와 20 대에게 패스트푸드 제품을 알려야 했으며 더불어 롯데리아 브랜드 에 대한 인지도를 높여야 하는 두가지의 과제를 동시에 수행하여야 했다.

이를 위해서 목표 소비자들이 많이 접하는 극장 광고를 적극적으로 활용하였으며, TV CF 를 제작하여 어린이들에게 인기가 높은 만화 영화 시간대를 중심으로 방송하였으며, 여고 생과 여대생이 즐겨보는 잡지를 중심으로 잡지 광고를 집행하였다. 이외에도 신문 광고에서 는 롯데리아 가맹점 개설을 유도하는 광고를 집행하였다. 한편 소비자들의 패스트푸드 제품 의 시용(trial)을 유도하기 롯데리아 제품올 시식해 볼 수 있도록 무료 시식권을 발행하였 다.

3.2 .4 제품라인의 다양화를 통한 경쟁적 차별점 확보

늘어난 경쟁 브랜드들과의 차별점을 학보하고 경쟁우위를 지키기 위해서 롯데리아는. 기존 
메뉴의 품질보완과 아울러 변화하는 소비자들의 욕구에 맞춘 재품올 출시하기로 결정하였 다.

1984년 피시버거와 리브샌드, 도시락 세트등의 메뉴를 출시하였다. 1984년 5월에 출시된 피시버거는 신선한 생선을 주원료로 만든 패티를 사용하여 여성들과 어린이를 목표로 만든 제품이었다. 이 제품에 대한 시장의 반응은 매우 좋은 편이었다.

도시락 세트는 피시 햄버거, 프랑크 소시지등으로 구성되어, 야외로 나가거나 운동 경기 를 관람할 때 식사 대용품으로 사용할 수 있도록 개발한 제품이다. 이 제품의 개발 배경에 는 프로 야구의 출범과 일반 소비자들의 야외 레져시간이 점차 늘어나는 추세에 따라서 전 통적인 김밥대용으로 사용올 수 있도록 하기 위한 것이었다. 도시락 세트 역시 유통을 강화 하여 기존의 유통망 이외에 홍익회를 통하여 판매하기 시작하였다.

한편 리브샌드는 소비자들에 욕구에 맞추어서 기존의 햄버거 스타일인 원형을 과감하게 탈피하여 직사각형에 가까운 형태의 햄버거를 출시하였다. 이 제품의 톡징온 갈비 스타일의 패티와 프렌치빵 그리고 바비큐향의 소스를 조화시켜 기존의 햄버거와는 차별적인 제품이었 다. 이후 리브 샌드는 롯데리아의 대표적인 제품으로 자리 잡게 되는데 그 배경에는 단순히 경쟁사보다 먼저 출시했다는 시기적인 이점뿐만 아니라 경쟁사의 유사 제품이 돼지 뒷다리 고기와 잡육을 섞어서 만드는데 비해서 상대적으로 원가가 비싼 돼지 전육을 사용하여 제품 의 질 항상에 노력한데 있다.

이후 롯데리아는 한국 소비자들 트렌드률 적극적으로 파악하여 제품 개발의 아이디어로 활용하게 된다. 또한 한국 소비자들에 입맛에 맞는 제품들을 연속적으로 출시하여 경쟁사와 차별적인 제품 라인업올 이루게 되었다.

\section{2 .5 브랜드 자산에 대한 보호}

기업간의 경쟁이 치열해 짐에 따라서 롯데리아 브랜드 자산을 적극적으로 보호하기 위한 조치도 아울러 실시되었다. 1979년 말부터 상표 등록 둥 산업 재산권을 출원하였다.

이에 따라 룻데리아 마크, 상호, 감자 튀김 용기, 컵뚜껑, 포크, 햄버거 훌더둥에 대한 의 장출원올 하였다. 한편 경쟁업체에서 "리아"라는 롯데리아의 뒷글자를 모방하는 사례가 늘 어나 "리아" "Ria", "알 아이 에이"를 둥록하였다.

\section{3 제 3 기 (패스트푸드와 외식업의 도약기: 1985년-1988년 ; 조직과 고객 관리 전략)}

\subsection{1 시장상황}

1985년에 들어서면서 꾸준하게 한국민의 소득수준이 중가되고, 86 년 아시안 게임과 올림 픽이 88 년도에 개최가 확정됨으로서 소비자둘의 기호패턴은 국제화률 지향하게 되고 이 결 과 식생활이 더욱 서구적으로 변화하게 되었다.

이러한 시장의 움직임에 따라서 햄버거를 중심으로 하는 패스트푸드 브랜드뿐만 아니라 기다 외국계 패스트푸드 업체의 본격적인 국내 진출이 시작되었다.

이시기에 피자헛, 피자인, 도미노를 비롯한 피자업계가 한국에 진출하였고, 패밀리 레스토 랑, 도넛, 프라이드치킨등 많은 업체들이 도입되었다. 이 결과 외식산업은 업체뿐만 아니라 업종간의 치열한 경쟁이 벌어지게 되었다. 후발주자인 외국계 업체들은 대규모 자본올 무기 
로 치열한 경쟁을 촉발하였다.

패스트푸드 업계에서는 1986년에 맥도날드가 한국시장 진출을 결정함에 따라서 시장올 방 어하기 위한 전략수립의 펄요성이 절박하게 대두되고 있었다. 그러나 실제적인 진출은 1988 년에야 이루어져서 롯데리아의 입장에서는 많은 대비책올 강구할 수 있었다.

이 시기의 햄버거 시장에서는 롯데리아를 비롯해 빅보이, 아메리카나, 혜미리, 버거킹, 커널리, 버거맨, 웬디스, 데리퀸, 달라스 햄버거, 후랜드 천, 그로리아, 메드리아, 탐스코 리아, 대관령햄버거, 아메리킹, 영 패밀리등의 업체가 경쟁을 하고 있었다.

한편 햄버거 시장에서의 경쟁상황은 롯데리아의 적극적인 시장개척과 다국적기업과 제휴 한 아메리카나와 빅보이가 추격전을 펼치는 양상으로 전개되었다.

아메리카나와 빅보이는 진출초기에 대형점포구축과 과감한 광고훙보 계힉을 시도하였으나 국내시장의 미성숙과 과다투자에 따른 단위점포당 수익성의 저하, 국내시장에서 쇠고기 원 료육의 확보문제등의 어려움울 격고 전략을 수정하였다.

\section{3 .2 경쟁을 위한 체제구축}

1985 년의 롯데리아의 최대목표는 매출액증대로 설정하고, 80 억원의 목표를 달성하기 위한 부문별 목표를 설정하였다. 그러나 신규 유통망 확대뿐만 아니라 유통망 확장에 효율성 개 념을 도입하기 시작하였다. 즉 신규점포개발은 30 개점을 개발하고, 상권분석을 통해서 A, $\mathrm{B}, \mathrm{C}$ 급으로 상권을 구분하여 투자개발비률 절감하기로 하였다. 이 결과 강원도 최초의 원주 점, 그 무렵 완공된 63 빌딩, 상봉터미널, 경주둥 그 시기별로 사회적으로 소비자들의 주목 율과 이용율이 높은 지역에 효과적으로 유통을 개설하였다. 뿐만 아니라 기존의 점포는 확 장하고 현대적인 인테리어를 도입하는 등 노후 점포의 전면 개보수 작업을 실시하였다.

제품 경쟁력을 강화하기 위해서 기초 원가율을 40\%이하로 축소한다는 목표를 설정하였으 며, 자재부문에서도 2-3\%의 절감을 목표로 하였다. 주방기기의 경우에도 문제점을 개선하는 등 경쟁을 대비한 적극적인 관리체제를 수립하기 시작하였다.

1985년까지 기장, 자재의 입출고, 경리및 회계등의 효율적인 관리를 위해서 전산화를 전 면적으로 실시하여 관리적인 측면에서 큰 성과를 거두었다. 1986년은 석유가, 한율, 금리등 의 3 저 현상에 힘입어 기업의 경영성과들이 전반적으로 좋아져 매출이 급성장하였으며, 사 내의 원가절감운동과 관리체제 구축에 힘입어 이러한 효과는 배가되었다.

\subsection{3 핵심고객 관계관리}

패스트뚜드 시장의 핵심고객이라고 할 수 있는 어린이 충에게 적극적으로 어필하기 위해 서 롯데리아 어린이회원을 모집하였다. 1985년 부산 남포점을 중심으로 부산지역에서 롯데 리아 어린이회원을 모집하여 어린이들 사이에 롯데리아 붐을 조성하였다. 경쟁사보다 훨씬 많은 전국적인 유통망을 이용하여 5 만명의 회원을 모집하였으며, 롯데자이언츠 야구단과의 연계를 톻해서 자연스럽게 스포츠 마케팅으로 유도하였다.

이 결과 약 4 만명의 어린이들이 회원에 가입하였으며, 이들을 통한 구전(words of mouth) 을 전파하여 큰 광고효과률 누리게 되었다. 이후에 롯데 자이언츠 구단과 공동마케팅을 전 개하여 1986년 리틀 자이언트 어린이 회원올 모집하는 과정에서 롯데리아 유통점을 통하여 전개함으로서 어린이들이 직접 매장올 방문하는 효과률 유도하여 브랜드 인지도 및 제품판 매와 연계하는 효과적인 촉진방법을 도입하였다. 또한 원주점에서는 어린이를 위한 인형극 을 적극적으로 후원함으로서 이 지역을 개척하기 위한 장기적인 촉진할동도 아울러 실시하 
였다.

\subsection{4 경쟁적 차별점을 확보하기 위한 신제품도입}

1986년 롯데리아는 여름 성수기에 대비하여 고유의 여름철 기호식품인 팥빙수를 패스트푸 드 제품으로 개선하여 판매하는 것을 고려하였다.

그러나 괕빙수가 서구식 패스트푸드 전문점인 롯데리아는 이미지와는 맞지 않는다는 반대 의견도 있었지만, 소비자 입장에서는 여름철에 패스트푸드 점에서 먹을 수 있는 메뉴가 음 료수 이외에는 부족하다는 점을 고려하여 적곡적으로 신제품으로 도입을 결정하였다.

롯데리아는 전통적인 팥빙수의 장점을 살리면서 패스트푸드 산업의 장점인 위생적인 측면 을 적극적으로 부각하여 소비자들로부터 큰 호응올 얼게 되었다. 이 결과 1986년 1년 동안 에 팥빙수의 판매 실적은 12 만여개가 판매되었으며, 1987 년에는 약 115 만개가 판매되었다. 이후에 팥빙수는 주력 메뉴로 자리 잡아 현재까지도 여름철 매출의 상당 부분을 차지하고 있다. 경쟁 업체들도 이률 모방하여 팥빙수를 메뉴로 출시하였다.

3.4 제 4 기 (패스트푸드 산업의 성장기: 1989년-1992년 ; 롯데리아의 주요 경쟁자 대비 차별화전략)

\subsection{1 시장상황}

1989 년 국내의 외식시장 규모는 8조5천억원으로 추정되었으며, 1990 년에는 10 조원을 넘어 서 1991년에는 12조 1992년에는 15조라는 큰 시장올 형성하였다. 1989년의 1인당 국민소득 은 5000달러로서 패스트푸드 산업이 본격적으로 성장하는 기준을 돌파하였으며 1992년에는 7000 달러에 근접하였다. 가계 소득은 1991년 처음으로 100 만원대를 넘었으며 가계수지혹자 도 288에 달해서 국민들은 비교적 여유 있는 소비 생활을 누릴 수 있게 되었다.

1988년 서울 올림픽을 기점으로 맥도날드를 비롯한 다양한 외식 업체들이 한국에 진출했 다. 이에 자극을 받은 한국 업체의 난립으로 과당 경쟁 속에 많은 업체들이 도산을 하였다.

1990 년대를 맞이하여 한국의 패스트푸드 산업은 새로운 성장기로 접어들어 급격한 시장 성장을 하였다. 이처럼 외식 산업의 급격한 성장은 그때까지 한국에 진출하지 않았던 타코 벨(tacobell)과 시푸드(sea food)등 다른 외식 업체의 한국 시장으로의 진입을 불러일으콨 다. 이 시기에는 롯데리아률 비롯한 맥도날드, 버거킹, 하디스, 웬디스둥은 시장 점유율 확 대률 통한 선두 경쟁에 나서 적극적인 유통망 중설에 나섰다.

맥도날드는 1988년 압구정 동에 1호점을 개설하고, 국내에서 후발 주자의 약점을 극복하 기 위해서 프리미엄 전략을 시행하였다. 즉 한국 시장에서의 경쟁은 고품질, 고가격 전략을 실시하였다. 이 결과 맥도날드는 시장도입 초기의 고전을 면치 못하였다. 한국 시장에서의 초기 진출이 부진한 것으로 나타나자 결국 미국의 맥도날드 본사는 세계 최초의 실패를 하 지 않기 위해서 또 다른 맥도날드를 한국 지사를 설립하였다. 맥도날드 코리아는 부산권을 관할하는 맥킴과 서울권을 관할하는 신맥이 둥장하였다.

\section{4 .2 지속적인 유통망확장과 제품 품질, 유형의 차별화 전략}

롯데리아는 경쟁자들의 유통망 확장 정책에 적극적으로 대옹하여 1990년 중반이 지나면 전국적으로 500 개의 유통망을 만든다는 “롯데리아 7 개년 계획”을 수립하였다. 
1992 년 롯데리아는 115 개점의 유통점올, $\mathrm{KFC}$ 는 62 개점을 , 맥도날드는 19개점을, 그리고 다국적 패스트푸드 업체중에 한국 시장에 제일 먼저 진출하였던 버거킹은 16 개점, 하디스와 웬디스는 각각 10 개와 13개점이 있었다. 한편 1995년 롯데리아는 200호점, 1996년 300호점, 1998 년 400호점을 개설하였으나, 맥도날드는 1998년에 100호점을 개설하였다.

이렇게 확장된 유통망을 지원하기 위해서 영호남지역에서 물류를 전담할 수 있는 대구 물 류센터를 개설하여 신선한 원부자재를 빠른 시간에 배송할 수 있는 체제를 구축하였다. 이 러한 물류센터의 설립은 제품의 신선도를 높이는 결정적인 역할을 하였다.

한편 유통망확장에 따른 유통점의 서비스 표준화와 효율화를 위해서 해외연수와 교육 시 스템을 재정비, 강화하여 설정된 유통망에서 최대의 효과를 달성하려는 노력을 기울였다.

롯데리아는 시장에서의 주요한 경쟁자들이 부상하기 시작하자 신제품 개발과 공격적인 마 케팅 전략을 전개하였다. 특히 다국적 패스트푸드 기업들이 전세계적으로 동일한 메뉴를 중 심으로 표준화전략을 구사한데 반해서 롯데리아는 현지화 전략으로 맞대응을 하기로 하여 매년 지속적인 신제품 개발을 하기로 전략방향을 설정하였다. 1992년 9월에는 한국인의 전 통음식으로 자리잡고 있는 불고기를 햄버거와 결합시킨 불고기 버거를 출시하여 매출 신장 의 절대적인 계기를 마련하였다.

\section{5 제5기 (패스트푸드 산업의 브랜드 정립기 : 1993년-1997년 ; 경쟁우 위 확보를 위한 고객만족 전략)}

\subsection{1 시장상황}

1990년대 중반기를 접어들면서 국내 패스트푸드 시장은 점차 중요한 경쟁 브랜드를 중심 으로 재편되어 나갔다. 일부 외국계 브랜드와 영세 군소 업체가 시장에서 퇴츨되었으며, 신 규 업체가 시장에 둥장하기는 하였으나 기존 업체들을 위협하지 못하는 안정된 경쟁 구도로 나갔다. 시장은 롯데리아률 선두로 맥도날드, 웬디스, 하디스둥의 기존 4 대 빅 브랜드들의 경쟁 더욱 치열지는 양상으로 변하여 갔다.

이들 브랜드둘은 공통적으로 시장 장악을 위해서 모두 핵심 상권 중심의 유통망 확보 전 략을 전개해 나갔기 때문에 유통망 악보를 중심으로 하는 경쟁은 유례 없이 치열하였다.

한편 패밀리 레스토랑 시장에서의 신규 업체들의 진출이 두드러졌으며, 피자 시장에서도 피자 헛의 고속 성장과 함께 중소 브랜드들이 둥장하여 피자의 대중화를 유도하였다. $\mathrm{KFC}$ 를 선두로 하는 프라이드 치킨 시장에서는 1993년 파파이스가 강력한 후발 브랜드로 등장하였 다.

1993년의 약 7500 달러의 1 인당 국민 소득은 1995년 드디어 1 만달러를 넘어섬으로써 외식 시장의 급속한 성장으로 이어졌는데, 국내 외식 시장의 경우는 1992년 15조원을 넘어선 이 후 1995년에는 18조원이 넘는 것으로 추정되었다. 한편 도시 근로자의 월평균 소득은 1993 년 150 만원, 1995 년에는 190 만원대로 들어섰으며, 가계지출중 식료품비에서 와식비가 차시 하는 비율도 $33 \%$ 를 넘어서 큰 시장규모를 형성하였다.

이와 같은 시장 환경하에서 롯데리아는 이 시기의 경영 방침을 보다 더 과감한 성장 전략 으로 정하고 경쟁력을 강화하는데 초점올 맞추었다. 이률 위해서 이제까지 펼쳐 온 유통망 확보 전략을 가일충 강화하고 그에 따른 조직 보강문제률 주요 과제로 선정하였다. 또한 크 게 확대된 회사 조직을 안정화시키기 위해서 노사 협조 체제 강화, 업무 환경 개선, 복리 
후생 증진에 대해서 주력하기로 했다.

\subsection{2 경쟁범위의 글로벌화 및 조직 안정화 전략}

1994년 2년동안의 준비 끝에 총 125만달러를 부입하여 국내 브랜드로는 최초로 중국 북경 천안문광장 인근에 중국 롯데리아 1 호점을 개설하였다. 여기서 판매하는 제품은 한국에서 직접 관리함으로써 품질과 서비스 측면에서 한국과 같은 수준을 유지하도록 하였다.

이 당시 북경에는 이미 맥도날드가 1992년에 진출하여 세계 최대 규모의 매장을 운영 중 이었다. 롯데리아가 중국에 개설한 두 번째 유통점에서는 개점 3 일만에 맥도날드 매장의 $80 \%$ 에 해당하는 매출을 나타내는 등 중국에서도 큰 인기롤 얻게 되었다. 1995년에는 이러한 유통망 확장 전략을 추진한 결과 200호점을 개설할 수 있었다.

1996년 이후 경기가 어려운데도 불구하고 지속적인 유통망 확장 전략을 구사하여 기존의 유통망보다 수를 두배 가까이 늘린 배경에는 IMF 사태가 사업 확장의 호기라고 판단 것이 주효하였다. 그 것은 외식 업계에서 햄버거나 치킨류는 비교적 다른 음식료에 비해서 상대 적으로 저가의 제품들로 구성돼 있어 상대적으로 경기를 덜 타는데다 실업의 급증과 이의 대안으로서 창업형 가맹점 수요가 급격하게 늘어나 오히려 유통망학장을 할 수 있는 여건이 갖춰져 있었다. 그리고 단기간내에 성과로 보면 대성공이라고 할 수 있었다.

이러한 확장된 유통망을 뒷받침하기 위해서 롯데리아는 1996년까지 서울, 용인, 대구, 김 해등지에 물류 센터를 확보해 경쟁사보다 신선한 원, 부자재룰 빠르게 공급할 수 있었다. 또한 단순한 유통망학장에만 그치지 않고 현대적이면서 밝고 깨긋한 분위기를 연출하기 위 해서 신세대 소비자들이 선호할만한 매장의 실내 인테리어를 경쟁공모를 통해서 선발하였다. 이 과정을 통해서 선발된 디자인은 향후 매장시설의 표준화률 통해서 신설유통점에 적용시 켜 나갔다.

한편 조직구성원의 직장에 대한 소속감과 몰입을 높이기 위한 다각적인 행사를 실시하였 다. 먼저 “번즈 위의 참께” 라는 사보를 발행하여 직원들간의 비공식적인 커뮤니케이션 채 널올 마련하여 직장생활내의 공감대를 형성할 수 있도록 하였다. 또한 일본 롯데리아와 연 계하여 당시만해도 파격적인 두달간의 일본 연수를 통해서 직원들에게 일본에서의 노하우를 한국에 이식할 수 있도록 하는 기희를 마련하였다.

\subsection{3 고객 만족을 위한 서비스전략}

롯데리아는 1993년 매장을 방문하는 고객들에게 보다 쾌적한 분위기를 제공하기 위해서 “빚내기 운동” 을 전개하였다. 전개 기간 동안 고객의 입장에서 매장뿐만 아니라 점포 내 의 지저분한 곳을 제거하여 고객에게 깨끗한 이미지를 제공하고, 근무자들에게 깨끗합의 중 요성을 강조하는 운동이었다.

한편 매년 고객 만족을 위해서 사내의 서비스 경진 대회를 개최해 왔다. 서비스 경진 대 회는 약 1 개월 동안 실시되며 참가팀끼리의 3 차에 걸친 치열한 경합을 벌리게 된다. 특히 1993년에는 "빛내기 운동" 의 후속적인 운동으로서 $4 \mathrm{~S}$ 운동을 전개하였다.

$4 \mathrm{~S}$ 는 미소(smile), 신속(speed), 정성(sincerity), 고운말(speaking)의 약자로서 밝은 표 정, 정성스러운 태도, 정확한 표현, 고운 말씨률 통한 친절한 표현등을 핵심으로 하는 것이 었다.

특히 이 운동을 전개하면서 슬로건올 “우리는 햄버거를 판매합니다" 에서 "우리는 QCS를 고객에게 드립니다"로의 영업방침올 변경하였다. 
한편 1994년에는 경쟁력 강화차원에서 고객상담센터를 설치하고 고객의 불만사항을 해당 부서에 전달하여 즉시 시정하도록 하였으며, 추후 재발방지에 만전을 기하였다.

\subsection{4 경쟁우위 확보를 위한 제품 개발}

이 시기에도 지속적으로 신제품을 출시하였다. 1993년에는 치킨버거를 출시하였다. 치킨 버거는 시장 세분화결과를 바탕으로 저 지방올 분화는 여성충과 성인층을 대상으로 개발된 제품이다. 치킨버거의 패티는 지방질이 적은 닭고기 가슴살을 선별하여 제조된 것으로 비만 때문에 지방을 기피하는 소비자들의 욕구를 반영한 제품이다. 이 제품은 소비자들로부터 큰 반응을 일으켜 출시된 두달 사이에 32 만개가 판매되었다.

한편 94 년에는 스테이크 버거와 휘시버거가 출시되었다. 스테이크 버거는 기존의 햄버거 패티 모양이 원형인데 반해서 사각형의 패티가 들어 있으며, 두툼한 비프 스테이크가 부드 럽게 씹히도록 만든 제품이다. 휘시버거는 일종의 새우 버거의 라인 확장 제품으로서 담백 한 햄버거 제품을 선호하는 소비자들의 입맛에 맞춘 제품이었다. 이들 제품들은 연말에 출 시하였는데도 불구하고 스테이크 버거는 50 만개이상, 휘시버거는 10 만개 이상 판매가 되었 다.

95년에는 신제품으로 더볼버거가 출시되었다. 이 제품은 “맛도 두 배, 영양도 두 배” 라 고하는 개념으로 기존 제품에 비해서 크기도 늘리면서 패티를 2 장 넣은 제품이다. 이 제품 은 기존의 햄버거로는 양이 부족한 청소년들을 목표로 출시된 제품이다.

96년에는 핫 화이어 윙과 내츄럴 포테이토를 출시하였으며, 연말에는 우엉버거, 영버거, 로얄버거, 리브샌드등을 출시하였다. 이중에 시장에서 칠수한 제품도 있지만 리브샌드등은 아직도 주요한 메뉴로 판매가 되고 있다.

\section{5 .5 시장 선도기업으로서의 기업 이미지 관리}

패스트푸드 산업의 선도 브랜드로서 롯데리아는 93 년 회 공동 목표인 환경 보존 및 공해 방지를 위한 쓰레기줄이기 캠페인에 적극 동참하였다. 각 유통점에서 사용하는 비널류에는 광분해 효소를 첨가한 썪는 비널 제품을 이미 사용하고 있었으며, 한걸음 더 나아가 프라스 틱, 스티로폼둥의 용기를 종이류로 교체하여 사용하기로 하였다.

95년에는 각 유통점에서 사용한 식용유를 수거하여 협력사인 서울 성원 유지에서 재활용 세탁비를 생산하여 고객들에게 제공하였고, $\mathrm{YMCA}$ 를 비롯한 사회 단체에도 공급되었다.

\section{6 제6기 (패스트 푸드 시장의 양대 브랜드 각축시대 ; 햄버거 가격 전쟁 1998년- 2001년)}

\subsection{1 시장상황}

1998 년은 국가적으로 경기침체가 가속화되어 많은 실직자가 양산되었으며, 1 인당 국민소 독은 전년도대비 절반이하로 떨어져 모든 소비산업은 정지되다 시피 하였다. 그러나 햄버거 를 중심으로 한 패스트푸드산업은 상대적으로 가격이 저렴하여 패밀리 래스토랑등 다른 외 식산업보다는 덜 타격을 입기도 하였다.

1998년 롯데리아는 경쟁브랜드들과 치열한 경합 끝에 한국의 관문인 김포공항점을 유치하 는데 성공한다. 매장규모는 40.7 평이며, 연간사용료는 2 억 5000 만원을 지불하였다. 이 유통 
점은 공항의 관문인 김포공항에 진출함으로서 향후 전국 주요 공항에 진출할 수 있는 교두 보를 마련했다는 점에서 의의가 있었다.

1999년에 들어서 패스트푸드산업은 롯데리아와 맥도날드의 가격전쟁에 휘말리게 된다. 선 제 공격은 롯데리아로부터 시작되었으며 평균 20-50\%의 가격인하 판촉올 연속적으로 실시하 게 되었으며 현재까지도 이 가격인하전쟁은 계속되고 있다.

\section{6 .2 사회공헌 활동 강화 및 조직의 효율성 강화}

1998년부터 롯데리아는 시장선도기업으로서 사회에 대한 기업의 공헌을 강조하였다. 이러 한 활동의 배경에는 아직 국가적으로 경제가 매우 침체되어 있었기 때문이었다. 이에 따라 서 실직자 결식아동돕기 켐페인, 순직 경찰유가족 자녀 장학금지원, 수해복구지원활동, 글 로벌 에티켓운동 동참등 기업의 사희적인 책임을 실천해 나가는데 앞장서기 시작하였다. 뿐 만 아니라 건전한 식음료 문화를 정착시킨다는 것을 기업의 경영목표로 삼고 정직한 식품을 제공하기로 하였다.

그 시기에 경쟁사 불고기 버거가 돼지고기를 구워서 만든 것임이 밝혀져 롯데리아의 불고 기 버거까지 매출이 떨어지는 사태가 발생하였다. 이를 대처하기 위해서 롯데리아는 소를 캐릭터로 포장과 광고에 등장시켰으며 경쟁제품과의 차별성을 강조하였다. 또한 위기를 기 회삼아 불고기 버거를 1992년 가격으로 판매하는등 대대적인 판촉에 들어간 결과 사태이전 의 매출로 회복할 수 있었다.

또한 어려운 경영환경율 극복하기 위해서 조직을 더욱 효율적으로 구성하고, 현장중시 경 영방침을 설정하였다. 이에 따라서 지점장 전결권을 확대하고 지점 담당인력의 담당 지점수 를 대폭 낮추어 지점의 문제점에 적극적으로 대처토록 하였다.

\subsection{3 햄버거 가격전쟁}

1999년 롯데리아 제품의 가격 인하를 계기로 롯데리아와 맥도날드는 치열한 햄버거 가격 전쟁에 돌입하였다. 가격 경쟁에서 룻데리아는 지속적으로 창업 초기부터 관리비를 비룻한 원가절감에 나섰고, 원자재의 $80 \%$ 이상을 롯데계열사에서 조달하며, 매출규모가 이미 규모 의 경제에 들어섰기 때문에 상대적으로 유리한 입장이다. 즉 롯데햄 롯데칠성 롯데제과 둥 계열사들로부터 안정적으로 원료를 공급받을 수 있으며, 더구나 규모의 경제와 구매력 파워 를 구현할 수 있기 때문에 원가경쟁력이 상당히 높은 편이다.

<표 1>은 2000년에 실시한 주요한 패스트푸드 3개 브랜드간의 가격인하률 중심으로 한 판 촉내용이 나타나 있다. 내용을 보면 20-50\%까지의 할인으로 이루어져 경쟁이 매우 치열하고 다양하게 벌어지고 있음을 볼 수 있다.

가격할인을 중심으로 하는 판촉은 더욱 치열하게 벌어져 2002년에는 몇몇 톡정 품목을 5 백원 또는 1천원에 판매하는 행사를 정기적으로 벌여 중소 패스트푸드업체들은 이중위험에 놓여 있다.

2002 년 7 월 맥도날드는 지난달 전국 3 백50개 매장에서 최저가 상품안 '맥도날드 햄버 거'(1천1백원)를 6 백원 할인된 5 백원에 판매했다. 이 가격은 롯데제과의 코팅검인 자일리 톨검 6 알 1 팩 가격과 똑같다. 할인 판매된 '맥도날드 햄버거'는 빵 속에 고기패티 피클 양 파 토마토케첩 등이 들어간 것으로 할인행사에 힙입어 4 월에 비해 7 배나 더 팔린 것으로 집 계됐다. 
<표 1> 2000년 패스트푸드 주요 브랜드의 판촉내용

\begin{tabular}{|c|c|c|c|}
\hline 구분 & 롯데리아 & 맥도날드 & 버거킹 \\
\hline 1-3월 & $\begin{array}{l}\text { 사은품중정 } \\
\text { 할인 권중정- } 1000 \text { 원 } \\
50 \text { \%가격 할인 }\end{array}$ & $\begin{array}{l}\text { 약30\%가격할인 } \\
\text { 경품중정-PC/MP3. }\end{array}$ & $\begin{array}{l}\text { 세트 매뉴구입시 } \\
\text { 인형할인판 매 }\end{array}$ \\
\hline 4-6월 & $\begin{array}{l}\text { 20-50\%가격할인 } \\
\text { 사은품중정-포켓몬스터 } \\
\text { 세트구입+추가품중정 }\end{array}$ & $\begin{array}{c}1000 \text { 원할인쿠폰중정 } \\
\text { 셰트메뉴 구입시 } \\
\text { 인형할인판매 } \\
\text { 경품증정-올립픽 }\end{array}$ & $30-40 \%$ 가격할인 \\
\hline 7-9월 & $\begin{array}{l}30-40 \% \text { 가격할인 } \\
\text { 사은품중정 } \\
\text { 즉석행운권 }\end{array}$ & $\begin{array}{l}\text { 경품중정 } \\
\text { 할인쿠폰북운영 } \\
\text { 햄버거 하나더 주기 }\end{array}$ & $\begin{array}{l}\text { 30-40\%가격할인 } \\
\text { 스템프적 립/경품중정 }\end{array}$ \\
\hline 10-12월 & $\begin{array}{l}20-50 \% \text { 가격할인 } \\
\mathrm{CD} \text { 증정 } \\
\text { 사은품중정 }\end{array}$ & $\begin{array}{l}\text { 할인쿠폰배포 } \\
\text { 세트매뉴구입시 } \\
\text { 인형할인판 매 } \\
\text { 경품중정 }\end{array}$ & $\begin{array}{l}\text { 30-50\%가격할인 } \\
\text { 세트 매뉴구입시 } \\
\text { 인형할인판매 }\end{array}$ \\
\hline
\end{tabular}

맥도날드는 전체의 $3 \%$ 선에 그쳤던 할인 품목의 매출 비중이 지난달에는 매장별 매출의 15 20\%를 점유할 정도로 높아졌다고 설명했다.

롯데리아는 상대적으로 소비자들에게 제공할 수 있는 품목이 많아 유리한 위치에 있는데, 치즈버거 데리버거 새우버거 등 4 5개 품목 중 매월 품목을 바뀌가며 가격을 인하하는 전략 으로 맥도날드의 할인공세에 맞서고 있다. 이러한 가격할인 결과 롯데리아는 1 천 6 백원짜리 '데리버거'를 1 천원에 할인 판매해 월 50 만개 안팍이던 '데리버거'의 판매량은 15 배 수준 인 7 백 50 만개로 급중했다. 이어 2 천5백원짜리 '불갈비버거'를 $35 \%$ 할인된 1천6백원에 판매 하는 가격인하전쟁을 하고 있다.

\section{4. 룻데리아의 주요한 성공요인}

패스트푸드산업에서 20여년간의 기업을 운영한 롯데리아의 성적표는 1998년부터 동아일보 를 비룻한 각종 신문사들과 상공회의소등 기관에서 주관한 조사에서 대상을 잇달아 수상하 는 것으로 알 수 있다. 수상내용은 각 세품에 대한 마케팅 대상올 포함하여 유통점의 투명 한 관리에 대한 프랜차이즈 대상까지 다양한 상을 수상하였다. 또한 1998년 매경에서 발표 한 브랜드 가치에 대한 조사에서는 외국계 브랜드보다 브랜드력이 뛰어난 것으로 나타났다.

이러한 롯데리아의 성공요인은 마케팅 관점에서 다음의 몇가지 요소로 축약시킬 수 있다. 
<표 2> 시기별 롯데리아의 경쟁력 강화 활동

\begin{tabular}{|c|c|}
\hline $\begin{array}{c}\text { 구분 } \\
\text { (시기/ 롯테리아의 }\end{array}$ & 경쟁력 강화를 위한 롯데리아의 마케팅 활동 \\
\hline $\begin{array}{c}\text { 제1기 } \\
\text { 빰른 의사결정 }\end{array}$ & 시장의 가능성확인 및 새른 사업전개 \\
\hline $\begin{array}{c}\text { 제2기 } \\
\text { 핵심상권 유통망구축전략 }\end{array}$ & $\begin{array}{l}\text { 핵심상권을 중심으로한 유통망확보 } \\
\text { 고객만족 시스템 도입 } \\
\text { 목표소비자중심 광고도입 및 제품 시용 촉진활동 } \\
\text { 브랜드자산에 대한 적극 보호 }\end{array}$ \\
\hline $\begin{array}{c}\text { 제3기 } \\
\text { 조직과 고객관리전략 }\end{array}$ & $\begin{array}{l}\text { 효율성분석을 붕한 유통망확장 및 관리전산화 } \\
\text { 핵심고객의 회원화를 통한 고객관리 } \\
\text { 신제품 출시 }\end{array}$ \\
\hline $\begin{array}{c}\text { 제4기 } \\
\text { 경쟁사대비 차별화전략 }\end{array}$ & 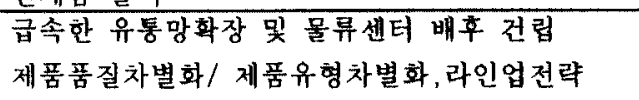 \\
\hline $\begin{array}{c}\text { 제5기 } \\
\text { 고객만족 전략 }\end{array}$ & $\begin{array}{l}\text { 롯데리아 브랜드 국제화 } \\
\text { 유통확장에 따른 조직안정화전략 } \\
\text { 고객만족전략( } 4 S \text { 운동전개) } \\
\text { 기업이미지관리 }\end{array}$ \\
\hline $\begin{array}{c}\text { 제6기 } \\
\text { 가격경쟁전략 }\end{array}$ & $\begin{array}{l}\text { 가격경쟁채제 구축 및 관리효울성 강화 } \\
\text { 사회공헌 기업이미지 강화 }\end{array}$ \\
\hline
\end{tabular}

\section{1 유통망확보를 통한 선두기업으로서의 경쟁적 우위유지}

시장 초기 진입(first mover)기업은 제품 판매를 위한 유통 경로 대안들중에서 최적의 대 안올 선택하여 설계할 수 있는 장점이 있다(Liberman \& Montgomery 1988). 시장에서 이같이 초기에 구축된 유통망들은 결국 후발진입기업들에게는 시장에서의 일종의 진입장벽으로서의 역할을 하게된다.

이러한 유통망의 확장은 결국 후발기업보다 큰 누적생산과 경헙올 실현하여 생산원가측면 에서 낮은 단위당 원가를 실현하는 것으로 이어지게 된다(Day \& Montgomery 1983). 이러한 대량생산과 이에 연결되는 대량소비는 결국 시장도입 초기에 경쟁자보다 높은 브랜드 인지 율과 이결과 얻어지게 되는 애호고객을 창출하게 된다.

롯데리아의 경우에 전형적인 초기 유통망 확장전략을 통한 수요의 확대가 규모의 경제로 이어지는 전략올 구사하였다. 조사에 따르면 1 이 전략은 소비자들의 태도 측면에서도 매우 적절한 전략이었음올 알 수 있다. 즉 롯데리아를 찾는 소비자들의 26.1\%가 거리가 가깝다 를 선호이유로 들고 있으며 두 번째로는 가격이 저렴하다를 22.6\%로 들고 있다. 한편 맥도 날드의 경우에는 $37.4 \%$ 가 가격이 저렴하다, $17.2 \%$ 가 거리가 가깝다를 들고 있다.

즉 햄버거 자체에 대한 소비자들의 평가는 경쟁사별로 별로 차이가 없으며 마케팅적인 요

1) 롯데리아 시장경쟁력 평가조사 2001.2. 
<표 3> 롯데리아와 맥도날드의 유통망 중가비율

\begin{tabular}{|c|c|c|c|c|c|c|}
\hline \multirow{2}{*}{ 년도 브래도 } & \multicolumn{3}{|c|}{ 전국 } & \multicolumn{3}{c|}{ 서울지역 } \\
\cline { 2 - 8 } & 1999 년 & 2000 년 & 종가율 & 1999 년 & 2000 년 & 증가율 \\
\hline 롳데리아 & 470 & 600 & $28 \%$ & 104 & 134 & $29 \%$ \\
\hline 맥도날드 & 175 & 240 & $37 \%$ & 62 & 74 & $19 \%$ \\
\hline
\end{tabular}

소가 구매에 결정적인 영향을 미치고 있음을 알 수 있다. 따라서 유통망 확장에 의한 선점 전략은 매우 적절한 전략이었음을 알 수 있다.

이러한 시장 진입순서에 위한 마케팅 활동에 따른 선두기업의 경쟁적 성과는 체계적인 관 계가 있음이 연구에서도 나타나고 있다(Lambkin 1988).

\section{2 끓임없는 한국적 신제품 개발전략}

롯데리아의 신제품 개발전략의 핵심은 햄버거를 한국적인 맛을 조화시킨다는 점과 개발과 정에서 우선 제품의 주요한 목표 소비자들을 정확하게 설정하고 이들에게 판매를 적극적으 로 소구하였다는 점이다. 신제품 개발은 92 년 불고기버거를 출시이후, 불갈비버거, 라이스 버거, 새우라이스버거 김치버거둥 한국형 버거를 만들어 나가는데 주력하였다.

세계 최초로 개발한 '불고기 버거'는 통상 햄버거에 들어가는 쇠고기가 잡육으로 이뤼진 '다진 고기(patty)'라는 점에 착안, 우리 입맛에 맞는 불고기용 재료를 사용해 햄버거를 만든 것. 이 제품은 요즘도 월평균 6 백 90 만개씩 팔려 나가며 롯데리아의 '캐시 카우' 역할 을 해내고 있다. 2001년 출시된 김치버거 역시 세계 최초로 개발됐다. 월평균 판매실적은 1 백 25 만개로 신세대들의 호옹이 낮은 제품이라는 점을 감안하면 기대치를 웃도는 히트상품이 다. 빵에 거부감을 갖고 있는 바뽄 직장인들은 라이스버거와 김치를 결합한 제품을 선호했 다.

현재 김치버거의 하루 판매량은 하루 5 만 6 만개이며, 월별 판매량이 1 백 80 만개에 이르며, 롯데리아의 월매출의 45 억정도를 차지하는 것 나타나고 있다.

2000년 출시한 롯데리아의 새우라이스버거 역시 성공한 신제품으로서 여성 고객층의 입맛 을 겨낭하였으며, 톡히 임산부들로부터 좋은 반응을 얼었다. 이 제품은 기존 버거제품과 흭 기적인 차별화를 기해서 쇠고기 야채 등을 넣은 야채 볶음밥을 빵 대신 사용했다.

불고기 패티 대신 여성 고객들이 선호하는 담백한 새우 패티를 사용해 여성들의 입맛을 자 극했다.

새우라이스버거는 라이스버거 계열 제품을 다양화하자는 전략에서 개발됐다. 롯데리아는 라이스버거의 인지도에 비해 여성 고객층 수요가 상대적으로 낮다는 것을 감안해 잠재 수요 층을 개발하기 위해 새우라이스버거를 내놓았다. 또한 새우라이스버거는 "햄버거는 간식"이 라는 고정관념을 파괴한 제품으로 포지셔넝시키기 위해서 출시되었는데, 햄버거 빵 대신에 볶음밥을 사용한 것도 이 때문이다. 이 결과, 햄버거도 한끼 식사로 충분하다는 신세대적인 사고방식에 부응해 식생활패턴을 바꾸는데도 일조했다. 이 제품은 시장에 출시된후에 지속 적으로 월 30 만개 이상씩 팔릴 정도로 인기가 높다.

또한 선두기업의 제품들은 소비자들의 선호구조에 영향올 미쳐서 이상적인 선호를 선두기 
업의 제품에서 추론하여 판단하기 때문에 선두기업의 제품들은 소비자의 선호구조에서 매우 중요한 위치를 차지하게 된다(Carpenter \& Nakamoto 1999).

\section{3 고객만족 지향적 서비스 체제구축}

직원들의 전문성 확보와 패스트푸드점의 특성에 맞는 매장관리를 위해 운영하고 있는 '햄버거 대학' (2개월 과정)의 경우 벌써 1 백 83 기 졸업생을 배출한 상태다. 또 점포장을 나 간지 1년이 지나면 반드시 본사에서 재교육을 받도록 해놓았다. 고객서비스팀을 운영하면서 정기적인 서비스 교육도 실시하고 있다.

서비스 품질을 나름대로 '규격화'한 것도 롯데리아의 강점으로 들 수 있다. 롯데리아는 일관된 서비스 품질 유지를 위해 고객클레임 제도, 모니터링 제도, 엔젤 제도둥을 활용하고 있다. 고객들의 불만은 홈페이지(www. lotteria.com)나 '080 고객의 전화' 롤 통해 실시간으 로 접수되며 현장에서 즉시 처리된다. 모니터링 제도는 모니터 요원들이 고객올 가장해 수 시로 주요 매장을 방문하는 제도로 일종의 내부통제 장치다. '엔젤'은 서비스 전담요원을 일컨는 용어로 각 매장별로 $3 \sim 4$ 명씩 배치돼 각종 고객 불편사항을 돌봐주는 역할을 한다.

<표4> 경쟁사 대비 고객만족도 조사결과 (단위 점)

\begin{tabular}{|c|c|c|c|c|c|c|c|}
\hline \multirow{2}{*}{ 구분 } & 소비자학회 & \multicolumn{2}{|c|}{ 한국갤럽 } & \multicolumn{4}{|c|}{ NCSI } \\
\cline { 2 - 9 } & 96.6. & 98.12 & 99.5 & $98.4 / 4$ & $99.4 / 4$ & $00.4 / 4$ & $01.4 / 4$ \\
\hline 롯데리아 & 54.4 & 61.5 & 62.3 & 59 & 59 & 65 & 67 \\
\hline 맥도날드 & 66.8 & 62.2 & 62.7 & 60 & 60 & 64 & 66 \\
\hline 버거킹 & 65.9 & 61.0 & - & 61 & 63 & 65 & 66 \\
\hline $\mathrm{KFC}$ & 62.7 & 61.6 & 61.6 & 61 & 62 & 63 & 66 \\
\hline 파파이스 & 56.4 & 60.8 & - & 63 & 63 & 67 & 65 \\
\hline
\end{tabular}

\section{4 지속적이며 효율적인 광고활동}

롯데리아의 2000 년 광고비는 맥도날드에 비해서 1.2 배에 달하며, 지난 2 년간의 광고량도 상대적으로 많은 것으로 나타나고 있다. 이러한 광고의 SOV(Share of Voice)는 결국 소비자 들의 인지도상승과 지속에 효과적으로 연결되고 있기 때문이다.

광고내용측면에서 조사결과 소비자들은 롯데리아의 광고에서 $22 \%$ 의 응답자가 양미라둥의 모델을 회상하며 이를 통해서 광고메시지를 인출해내는 것으로 나타나 지속적인 모델을 중 심으로한 내용이 광고효과로 연결되고 있다. 이에 비해서 경쟁사들의 광고는 광고효과 조사 결과 소비자들에게 두드러지게 회상되는 내용이 많지 않아 롯데리아는 상대적으로 효과적인 광고활동을 해왔음을 알 수 있다. ${ }^{2}$

2) 롯데리아 시장경쟁력 평가조사 2001.2 


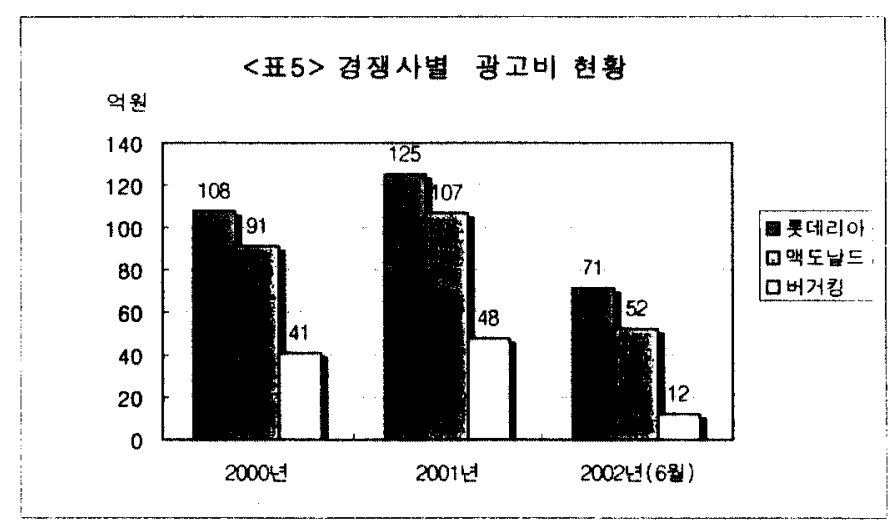

\section{5 전문 경영인체제}

롯데리아는 롯데그룹이 계열사로 출범하여 그동안 서비스업에서 활동한 전문경영인을 영 입하여 백화점등 이외의 서비스 체제를 롯데리아에 이식할 수 있는 기회를 가졌다는 것을 장점으로 들 수 있다. 시장 진출당시인 1979년에는 한국시장에서 아직 서비스 산업이라고 할 수 있는 것이 별로 없었으며, 서비스라는 개념도 완전하게 정립되지 않올때에도 다른 경 쟁사보다는 나은 서비스 체제를 갖춘것도 바로 이러한 배경에서 나온 것이라고 할 수 있다. 그러므로 최근 강조되는 전문인 경영체제하에서 관리체제를 이미 실현함으로서, 소유경영위 주인 다른 경쟁사보다 빠른 시일내에 경쟁력을 갖출 수 있었다.

한편 전문경영진들은 각자의 경헙을 바탕으로 제휴마케팅과 촉진전략을 전개함으로서 롯 데리아가 다양한 마케팅활동울 할 수 있었던 것이다.

\section{5. 롯데리아의 향후 전략적 과제}

현재의 햄버거를 중심으로하는 패스트푸드 산업은 1 위를 지키려는 롯데리아와 맥도날드간 의 치열한 경쟁구도로 이루어져 있다. 이러한 구도를 지키기 위해서는 롯데리아의 입장에서 고려해야하는 몇가지 고려점을 살펴보기로 하자.

첫째, 브랜드 개성의 지속적인 관리가 펄요하다.

현재의 롯데리아는 경쟁사대비 브랜드 인지도측면에서는 높은 평가를 받고 있지만, 브랜 드의 개성차원에서의 보다 정교한 전략수립이 필요하다. 기존의 연구에서도 소비자들의 개 성과 브랜드의 개성의 차이가 작을수록 구매의도가 높아지는 것으로 나타나고 있어서 이에 대한 관리가 필요하다. 지금까지의 조사에 따르면 롯데리아의 브랜드개성평가에서는 여성 
적인/서민적인/친근한/대중적인/따뜻한 성격으로 평가되는데 반해서 맥도날드는 유명한/전 통적인/앞서가는/밝은/명랑한/세계적인, 그리고 버거킹의 경우에는 남성적인/무뚝뚝한/부유 한/세련된/깔끔한/분위기로 나타나고 있다. 그러나 이러한 개성을 다시 소비자들의 사용상 황변수로 보면 다량소비자들은 맥도날드에 대해서 더 친근감을 느끼고 있다. 따라서 시장세 분화를 통한 전략적인 접근이 필요하다고 본다.

둘째, 브랜드 자산의 보다 정교한 전략적 관리가 필요한 시점이다. 브랜드 관리에서 브랜 드에 대한 연상은 브랜드 자산의 형성에서 매우 중요한 역할을 하게 되는데(Keller 1993), 현재 롯데리아 브랜드에 대한 연상에서는 광고에서의 모델이 차지하는 비중이 약 $20 \%$ 로 매 우 높은 것으로 나타나고 있다. 한편 맥도날드의 경우에는 맥도날드률 상징하는 로고의 "M"이 가장 높은 비율로 나타나고 있음을 비추어 불 때, 롯데리아와 적접적인 관계가 있는 단서가 연상화될 수 있도록 브랜드를 관리해 나가는 것이 바람직하다고 판단된다.

셋째, 시장세분화개념을 더욱 강화하여 사용자에 따른 전략을 마련하여야 할 것이다. 다 량 사용자 이론(heavy user theory)에서와 같이 패스트푸드제품의 다량사용자에 대한 전략적 접근을 고려하여야 할 것이다. 현재의 판촉방법으로는 이러한 다량사용자에 대한 소구가 미 홉할 수 있으므로 촉진방식의 전략적 제휴등 여러 수단올 활용하여 이들에게 소구할 수 있 어 야 할 것이다. 그러나 한편으로는 패스트푸드 산업의 특성상 모든 연령층에게 소구할 수 있도록 연합적 편익(benefit coalition)을 고려하여야 할 것이다.

넷째, 시장에서의 경쟁력을 잃지 않기 위해서는 시장에서 소비자들로부터 각광받고 있는 제품에 대해서 혁신적으로 교체하려는 의지를 가지는 것이다(Day 1990). 따라서 앞으로도 경쟁사보다 소비자들에게 소구될 수 있는 제품과 서비스 그리고 이를 소비자들에게 효과적 으로 전달할 수 있는 지속적이고 효율적인 마케팅 수단의 발굴이 경쟁적 우위를 유지시키는 관건이 될 것이다. 


\section{<참고문헌>}

Carpenter, Gregory S., Kent Nakamoto(1989), "Consumer Preference Formation and Pioneering Advantage," Journal of Marketing Research, vol.26(August), pp.285-298.

Day, George S., David B. Montgomery(1983), "Diagnosing the Experience Curve", Journal of Marketing, vol.47(Spring), pp.44-58.

Keller, Kevin Lane(1993), "Conceptualizing, Measuring, Managing Customer-Based Brand Equity", Journal of Marketing, vol.57(1), pp1-22.

Lambkin, Mary(1988), "Order of Entry and Performance in New Market", Strategic Management Journal, vol.9, pp.127-140.

Liberman, Marvin B., David B. Montgomery(1988), "First-Mover Advantage", Strategic Management Journal, vol.9, pp.41-58.

Day, George, S, 손영석, 서정희역(1995), Market Driven Strategy; 글로벌 시대의 시장경쟁 전랴, 서울, 21 세기북스.

롯데리아 2000년 시장경쟁력 평가 및 브랜드 이미지에 대한 소비자 보고서(2001). 대홍기 마케팅 컨설팅 그릅

롯데리아 20년사(1999), 롯데리아 